\title{
Environmental Impact Assessment (EIA) for Gilgel Gibe-2 Hydropower Project, Ethiopia
}

\author{
Tesfaye Hailu Estifanos \\ Department of Natural Resource Management, Wolaita Sodo University, p.o.box 138, Ethiopia
}

\begin{abstract}
Nowadays, political and public consciousness with regard to environmental issues combined by awareness of issues associated with climatically changes and interest in promoting sustainable development has led to growing of the international debate on the benefits derived from major water resources projects. Hence, all hydropower projects are subjected to environmental impact assessment. The Gilgel Gibe II project area is located on the South Western Ethiopian plateau. The cascade is located in the Jimma Zone Administration between the Gilgel Gibe and Omo rivers, some $250 \mathrm{~km}$ South-West of Addis Ababa and about $80 \mathrm{~km}$ North-East of Jima. The Gilgel Gibe is a tributary of the Great Gibe River, also known as Omo River downstream of the bridge of the highway Addis Ababa - Jimma. Most of the project component sites are in Yem Special Woreda of the Southern region. The powerhouse, access road, project camps and construction of other facilities are located in this Woreda. The general objective of the study is to identify the potential positive and negative environmental impacts of the proposed Gilgel gibe II hydropower project on the environment and propose possible measures for further mitigating the negative impacts. The Environmental Impact Assessment (EIA) of the Gilgel Gibe II project was done based on the EIA requirement for hydropower projects as referred from different EIA guidelines and materials. Moreover, past studies such as the Gilgel gibe II dam design, EIA, watershed management, Hydraulics and hydropower, and soil and land suitability study reports have thoroughly reviewed to get basic information on the biophysical and socio- economic conditions of the study areas. The main materials used to identify possible potential environmental impacts of the dam-reservoir and hydropower project is the ICID guidelines and checklists. Mitigation measures are required based on priorities to avoid or minimized the adverse impacts that will be resulted due to the project implementation. To this end, possible management or mitigation measures have proposed against identified negative impacts of the project. Although they can be managed through proper mitigation measures, the project may also result some significant adverse impacts on the environment. Therefore, proper mitigation measures need to be considered at each stages of the project implementation including construction to operation, if not it will result distressing challenges both to the environment and sustainability of the project.
\end{abstract}

Keywords: Environmental Impact Assessment, Gilgel gibe-2, Hydropower project

DOI: $10.7176 / \mathrm{IAGS} / 71-02$

Publication date: April $30^{\text {th }} 2019$

\section{Introduction}

Nowadays, political and public consciousness with regard to environmental issues combined by awareness of issues associated with climatically changes and interest in promoting sustainable development has led to growing of the international debate on the benefits derived from major water resources projects. Hence, all hydropower projects are subjected to environmental impact assessment [2].

Ethiopia has an abundance of rivers that provide the country with the potential for large sustainable energy resources in the form of hydropower. Recent power planning studies have estimated that Ethiopia's hydroelectric potential is in the order of $30,000 \mathrm{MW}$, a potential greatly in excess of foreseeable domestic demand. Currently only about one percent of the available total is being harnessed for generating hydroelectric power. Preliminary investigations have indicated that the most promising sites could be developed at lower costs than other power generation options.

Ethiopia's 10 year perspective plan for the period 1984 to 1993 recognized the importance of low cost energy as an incentive to industrial and economic development. At the same time, the plan realized that export sales could provide an attractive long term development opportunity. Neighboring countries are poorly endowed with water resources that can be converted to inexpensive energy and they face the continuing prospect of increasing oil imports in order to meet their own domestic demand [6].

The Gilgel Gibe project is one of the most attractive potential hydroelectric developments in the country. In extension of Gilgel Gibe I, the project called Gilgel gibe II was constructed on Omo basin to fulfill the hydropower requirement of the country.

The Gilgel Gibe II project area is located on the South Western Ethiopian plateau. The cascade is located in the Jimma Zone Administration between the Gilgel Gibe and Omo rivers, some $250 \mathrm{~km}$ South-West of Addis Ababa and about $80 \mathrm{~km}$ North-East of Jima. The Gilgel Gibe is a tributary of the Great Gibe River, also known as Omo River downstream of the bridge of the highway Addis Ababa - Jimma. Most of the project component 
sites are in Yem Special Woreda of the Southern region. The powerhouse, access road, project camps and construction of other facilities are located in this Woreda.

The proposed hydropower project will have various potential impacts on the environment. The potential impacts of the project may be positive or negative and can be various in nature, extent and significance to the environment. Therefore, EIA is required to evaluate the environmental consequences of the project and ensure that environmental impacts of the project are adequately considered before decisions are taken. This will help to minimize negative environmental impacts of the project on the environment, thereby facilitating inclusion of the principles of sustainable development in to the project area.

The general objective of the study is to identify the potential positive and negative environmental impacts of the proposed Gilgel gibe II hydropower project on the environment and propose possible measures for further mitigating the negative impacts. The specific objectives are to:

$\checkmark$ To identify and forecast the possible positive and negative impacts to the environment resulting from the proposed project.

$\checkmark \quad$ to provide mitigation measures which up on implementation will reduce or offset the negative impacts of a project resulting in a minimal level of environmental degradation

$\checkmark$ To measure the level of plan implementation and the degree of effectiveness of the environmental protection provisions.

\section{Policy, legal, and institutional framework}

\subsection{Institutional and administrative framework}

The following paragraphs discuss the institutional and administrative framework at the Federal and Regional level and organizations responsible for the preparation of environmental policy and technical guidelines.

\subsubsection{Federal Democratic Republic of Ethiopia}

The Federal Democratic Republic of Ethiopia (FDRE) comprises the Federal State and nine Regional State members. The power and duties of the Federal, Regional and Local governments have been defined by Proclamations 33 of 1992 and 41 of 1993, and 4 of 1995. Under these proclamations, duties and responsibilities of Regional States include planning, directing and developing social and economic development programs, as well as the protection of natural resources of their respective regions [5].

\subsubsection{Regional Government}

The Gilgel Gibe II Hydropower Project lies within the Jima Zone of the Oromiya Administration Region and the Yem Special Wereda of the Southern Nations and Nationalities Peoples Region (SNNPR).The Oromiya and SNNPR Regional Governments are two of the regional states established by the Federal Government. The regions have Zones and Weredas. The basic administration unit is the Wereda and each Wereda is sub-divided into Kebele and peasant/farmers associations. Each administrative unit has their own local government elected by the people. Based on the powers and responsibilities of the regional governments, the two Regional Governments have established Sectoral Bureaus, Commissions and Authorities.

\subsubsection{Environmental Protection Authority}

The Environmental Protection Authority (EPA) was re-established in October 2002, under Proclamation 295/2002, and is an autonomous government body reporting directly to the Prime Minister. It has a broad mandate covering environmental matters at federal level. The Proclamation sets out the main responsibilities and broad organizational structure of EPA and these may be summarized as follows:

$>$ Preparation of environmental protection policies and laws and to ensure that these are implemented

$>$ preparation of directives and implementation of systems necessary for the evaluation of the impact of projects on the environment

$>$ preparation of environmental protection standards and implementation of directives concerning soil, water and air

$>$ the conduct of studies on desertification and the co-ordination of efforts to combat it

$>$ to establish a system for EIA of projects, policies, strategies, laws and programs

$>$ to enforce implementation of this EIA process (i.e. review EIA reports) and the recommendations which result from it for projects that are subject to Federal licensing, execution or supervision

$>\quad$ to enter any land, premises or any other places that falls under the Federal jurisdiction, inspect anything and take samples as deemed necessary with a view to ascertaining compliance with environmental protection requirements

$>$ to ensure implementation of environmental protection laws

$>$ preparation of recommendations regarding measures needed to protect the environment

$>$ enhancement of environmental awareness programs

$>$ implementation of international treaties concerning the environment to which Ethiopia is a signatory

$>$ provision of advice and technical support to the regions on environmental matters

With these powers, EPA has the mandate to involve itself with all environmental issues and projects that 
have a federal, inter-regional (involving more than one Region) and international scope.

In view of the multi-sectorial nature of the EPA and the number of government agencies involved in various aspects of environmental management, overall co-ordination and policy review and direction is the responsibility of an Environmental Protection Council (EPC) within EPA. The responsibilities of the council shall include:

$>$ to review proposed environmental policies, strategies and laws, and issue recommendations to the Government,

$>$ based on report submitted to it by the Authority, evaluate and provide appropriate advise on the implementation of the environmental policy of Ethiopia; and

$>$ Review and approve directives, guidelines and environmental standards prepared by the Authority.

\subsection{National policies and strategies}

The following sections discuss the national policies and sectoral strategy background regarding environmental protection and EIA in Ethiopia.

\subsubsection{The Constitution}

The FDRE Constitution contains a number of articles that are relevant to environmental matters in connection with development projects, as well as to the environment in general. Article 43 gives the right to people to improved living standards and to sustainable development. Article 92 of Chapter 10 (which sets out national policy principles and objectives), includes the following significant environmental objectives:

* Government shall endeavor to ensure that all Ethiopians live in a clean and healthy environment,

* the design and implementation of programs and projects of development shall not damage or destroy the environment,

* people have the right to full consultation and to the expression of their views in the planning and implementation of environmental policies and projects that affect them directly,

* Government and citizens shall have the duty to protect the environment.

\subsubsection{Environmental Policy of Ethiopia}

The Environmental Policy of Ethiopia (EPE) was approved by the Council of Ministers in April 1997 (EPA/MEDAC 1997). It is based on the CSE which was developed through a consultative process over the period 1989-1995. The policy has the broad aim of rectifying previous policy failures and deficiencies which, in the past, have led to serious environmental degradation. It is fully integrated and compatible with the overall long-term economic development strategy of the country, known as Agricultural Development-Led Industrialization (ADLI), and other key national policies. The EPE's overall policy goal may be summarized in terms of the improvement and enhancement of the health and quality of life of all Ethiopians, and the promotion of sustainable social and economic development through the adoption of sound environmental management principles. Specific policy objectives and key guiding principles are set out clearly in the EPE, and expand on various aspects of the overall goal. The policy contains sectoral and cross-sectoral policies and also has provisions required for the appropriate implementation of the policy itself. The section of the EPE concerning EIA sets out a number of policies, key elements of which are summarized as follows:

$\checkmark$ recognition of the need for EIA to address social, socio-economic, political and cultural impacts, in addition to physical and biological impacts, and for public consultation to be integrated within EIA procedures

$\checkmark$ incorporation of impact containment measures within the design process for both public and private sector development projects, and for mitigation measures and accident contingency plans to be incorporated within environmental impact statements (EISs)

$\checkmark$ creation of a legal framework for the EIA process, together with a suitable and coordinated institutional framework for the execution and approval of EIAs and environmental audits

$\checkmark$ development of detailed technical sectoral guidelines for EIA and environmental auditing

$\checkmark$ development of EIA and environmental auditing capacity and capabilities within the Environmental Protection Authority, sectoral ministries and agencies, as well as in the regions

\subsubsection{Water Resource Policy}

The Ministry of Water Resources has formulated the Federal Water Resource Policy for a comprehensive and integrated water resource management. The overall goal of the water resources policy is to enhance and promote all national efforts towards the efficient and optimum utilization of the available water resources for socio economic development on sustainable bases. The policy is to establish and institutionalize environment conservation and protection requirements as integral parts of water resources planning and project development [6].

\subsubsection{Environmental Framework Legislation}

The following three Proclamations have been issued by EPA and they represent a framework building on the policies and strategies set out in the CSE and the EPE, which sets out basic and general provisions for the regulation of environmental matters in a coherent and holistic manner, and will be supplemented in due course 
by more sectors -specific legislation.

\subsubsection{Proclamation on Institutional Arrangement for Environmental Protection}

The Proclamation for the Establishment of Environmental Protection Organs, No. 295/2002, was issued to establish a system that fosters coordinated but differentiated responsibilities among environmental protection agencies at Federal and Regional Levels. The proclamation recognizes assigning responsibilities to separate organizations for environmental development and management activities on the one hand, and environmental protection, regulations and monitoring on the other is instrumental for the sustainable use of environmental resources, thereby avoiding possible conflicts of interests and duplication of efforts. A series of institutional mandates that would extend the powers and duties of the Environmental Protection Authority (EPA) and the Environmental Protection Council (EPC) beyond those defined in the enabling legislation, which established these bodies are also included. Powers and duties are also proposed in relation to Zonal, Wereda and Community Environmental Coordinating Committees, which will also be established.

\subsubsection{Proclamation on Environmental Impact Assessment}

The primary aim of the Proclamation on Environmental Impact Assessment (No. 299/2002) is to make EIA mandatory for specified categories of activities undertaken either by the public or private sectors, and possibly, the extension of EIA to policies, plans and programs in addition to projects. The provision of the proclamation includes:

* Projects will be subject to EIA and execution is subject to an environmental clearance from the EPA or Regional Government Environmental Agency, as applies;

* EPA or the Regional Agency, depending on the magnitude of expected impacts, may waive the requirement of an EIA;

* All other licensing agencies shall, prior to issuing of a license, ensure that either EPA or the regional Environmental Agency has authorized implementation of project; and

* A licensing agency shall either suspend or cancel a license that has already been issued, in the case that EPA or the Regional environmental agency suspends or cancels the environmental authorization.

Procedures that must be followed in the EIA process are described in the proclamation:

* A Proponent shall ensure that an environmental impact assessment is conducted and an environmental impact study report prepared by experts that meet the requirements specified under a directive issued by the Authority.

* The Authority or Regional environmental agency shall, after evaluating an environmental impact study report by taking into account any public comment and expert opinions:

* approve the project without conditions and issue authorization if it is convinced that the project may not cause negative impacts;

* approve the project and issue authorization with conditions that must be fulfilled in order to reduce adverse impacts to insignificance; or

* Refuse implementation of the project if the negative impact cannot satisfactorily avoided by setting conditionality of implementation.

\subsubsection{Proclamation on Environmental Impact Assessment}

The Proclamation on Environmental Pollution Control (No. 300/2002) is mainly based on the right of each citizen to a healthy environment, as well as on the obligation to protect the environment of the Country. The primary objective of the Proclamation on Environmental Pollution Control is to provide the basis from which the relevant ambient environmental standards applicable to Ethiopia can be developed, and to make the violation of these standards a punishable act. The Proclamation states that the "polluter pays" principle will be applied to all persons. Under this Proclamation, the EPA is given the mandate for the creation of the function of Environmental Inspectors. Article 7(1) of this proclamation gives the authority to ensure implementation and enforcement of environmental standards and related requirements to Inspectors (to be assigned by EPA or regional environmental agencies).

\subsubsection{Environmental Protection Authority's EIA Guideline}

In May 2000, as part of the ongoing effort to develop environmental legislation and guidelines in

Ethiopia, the EPA released the final draft of its EIA Guidelines document. This guideline follows the conventional pattern adopted in many other parts of the world. The guideline requires all projects to be submitted to an Environmental Screening to enable a decision to be taken as to whether the project is to be submitted to full EIA (in the case of projects which may have significant impacts) and are defined as falling under Schedule 1, or are of projects such a type or scale which does not justify full EIA, and therefore fall into Schedule 2. Schedule 3 projects are the ones who have no impact on the environment and do not require EIA. The proposed Gilgel Gibe II hydropower project is a category 1 and requires full EIA.

According to the Guideline, approval of an Environmental Impact Statement (EIS) is conditional and it is on compliance with environmental quality criteria, or other provisions stated in the EIS, and the approving 
authority may conduct audit and surveillance to ensure compliance during and after project implementation.

\section{Methodology of the study}

The Environmental Impact Assessment (EIA) of the Gilgel Gibe II project was done based on the EIA requirement for hydropower projects as referred from different EIA guidelines and materials. Moreover, past studies such as the Gilgel gibe II dam design, EIA, watershed management, Hydraulics and hydropower, and soil and land suitability study reports have thoroughly reviewed to get basic information on the biophysical and socio- economic conditions of the study areas.

The main materials used to identify possible potential environmental impacts of the dam-reservoir and hydropower project is the ICID guidelines and checklists. The procedures followed were the following:

$\checkmark$ Project site selection based on information availability and familiarity about the project site

$\checkmark$ collect and review previous relevant studies

$\checkmark$ refer standard guidelines and review legal-frameworks and legislations relevant to EIA

$\checkmark$ identify environmental parameters relevant for EIA analysis of the project

$\checkmark$ describing the potential negative and positive impact of the project

$\checkmark$ analyze the EIA of the project using the ICID checklists and

$\checkmark$ Evaluate Environmental impacts of the project

$\checkmark$ Propose mitigation measures to avoid or minimize adverse environmental impacts.

As field survey and discussion with target community did not carried out, the study is mainly depending on previous studies and theoretical background on the potential Environmental Impacts of dam/reservoir and hydropower development projects.

\subsection{Project description}

The cascade is located in the Jimma Zone Administration between the Gilgel Gibe and Omo rivers, some $250 \mathrm{~km}$ South-West of Addis Ababa and about $80 \mathrm{~km}$ North-East of Jima. The Gilgel Gibe is a tributary of the Great Gibe River, also known as Omo, River downstream of the bridge of the highway Addis Ababa - Jimma. Most of the project component sites are in Yem Special Woreda of the Southern region. The powerhouse, access road, project camps and construction of other facilities are located in this Woreda. The access road to the powerhouse is about $30 \mathrm{~km}$ from Fofa the capital town of the Woreda. The access road passes through Gormihangere, Meleka Kerzidoyo, Shosherna, Alman and Shosho rural kebeles of the Woreda. Bordering Yem is Gurage Zone on the North-East and Hadya Zone on the East, and South and Jimma (Oromiya) from North-West to SouthWest. Fofa town is situated in the central part of the Woreda. The road to Fofa branches off at Saja from the Main Addis-Jima asphalt highway.

\section{Map 1: The project area}
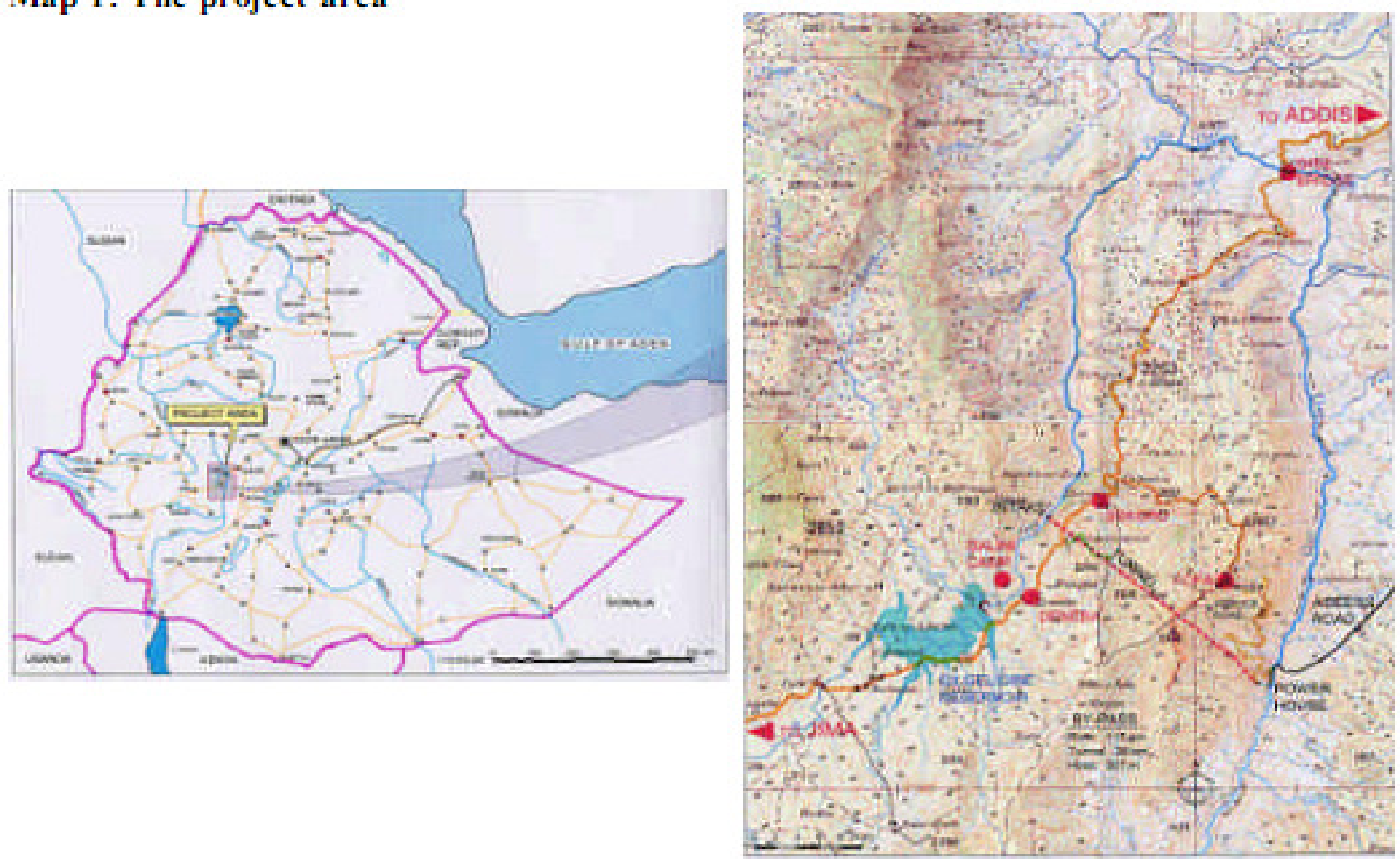

Fig 1: map of Gilgel Gibe-2 project site 
The proposed plant has the following basic features:

- Intake reservoir, 1.2 $\mathrm{Mm}^{3}$ useful capacities (alternative design, March 2004)

- $26 \mathrm{~km}$ power tunnel length $(\mathrm{D}=6.3 \mathrm{~m}, 0.25 \mathrm{~m}$ lining) of which

- $0.8 \mathrm{~km}$ constructed with Drill and Blast technology

- $25.2 \mathrm{~km}$ constructed with TBM technology

- $1.2 \mathrm{~km}$ length of N. 2 penstocks, average diameter $3.2 \mathrm{~m}$

- Power house outdoor

- Pelton N. 4 turbines, $105 \mathrm{MW}, 470 \mathrm{~m} \mathrm{Hn}, 25 \mathrm{~m} 3 / \mathrm{s}$ Q

- 0.44 plant factor $(0.46$ Gilgel Gibe I)

- 1,625 GWh energy produced annually

- Hydrology:

- About 4,300 km2 catchment area (about 4,200 km2 Gilgel Gibe I)

- Weir (alternative design, March 2004):

- $33 \mathrm{~m}$ height above ground

- $170 \mathrm{~m}$ width, approx. $38 \mathrm{~m}$ of total height

- Spillway (alternative design, March 2004):

-2,350 m3 /s max discharge flow (sill)

- Intake (alternative March 2004):

- 1,437.0 m a.s.1. flood level (Q=2350 m3 /s)

- 1,431.5 m a.s.l. normal operating level

- 1,424.0 m a.s.1. min operating level

- 1,422.0 m a.s.l. intake crest elevation

- Surge shaft:

- $88.0 \mathrm{~m}$ height

- $18.0 \mathrm{~m}$ diameter

- Power house (basic design, Oct 2003, layout under revision due to the new solution selected for the branches at the turbine inlet):

- 120x25x 36 maximum size

- $505.0 \mathrm{~m}$ max gross head

- $470.0 \mathrm{~m}$ design head (net head at average reservoir level)

- $101.5 \mathrm{~m} 3 / \mathrm{s}$ design flow

- $420 \mathrm{MW}$ installed power

- 1,430 GWh/y annual energy available to earn revenue

\section{Description of biophysical condition}

\subsection{Climate}

The climate in Ethiopia is related to the topography and to the movements of the Inter-Tropical

Convergence Zone (ITCZ) during the year. The amount of rainfall varies with topography, location and elevation. Annual average rainfall can be considered almost the same in project catchment area and in the release zone. All the considerations can be done on the data of the Sekoru meteorological station. The climate in most of the catchment falls within the category of humid tropical with a mono modal rainfall distribution. Mean monthly rainfall values show maximum in August for most of the stations in the catchment. Mean annual rainfall varies between $1800 \mathrm{~mm}$, where the Gilgel Gibe originates, to about $1100 \mathrm{~mm}$ where it joins Great Gibe. Rain fall in the Yem special wereda varies from 600 to $1800 \mathrm{~mm}$, registered respectively at Great Gibe gorge where the proposed power house is situated and at Fofa height. Mean temperature varies from $12^{\circ} \mathrm{C}$ at Fofa to $30^{\circ} \mathrm{C}$ at Great Gibe Gorge. The annual rainfall of the Gilgel Gibe catchment area varies from a minimum of $1,300 \mathrm{~mm}$ near the confluence with the Great Gibe River, to a maximum of about 1,800 $\mathrm{mm}$ in the Utubo and Fego mountains. Rainfall decreases throughout the catchments with a decrease in elevation. The average annual rainfall calculated over the whole Gilgel Gibe basin where it joins the Great Gibe River $\left(5,500 \mathrm{~km}^{2}\right)$ is $1,527 \mathrm{~mm}$; over the Deneba catchment $\left(4,225 \mathrm{~km}^{2}\right)$ it is $1,535 \mathrm{~mm}$; over the partial catchment between Asendabo and Deneba $\left(1,295 \mathrm{~km}^{2}\right)$ it is about $1,479 \mathrm{~mm}$, and over the partial catchment area between Deneba and the Great Gibe River $\left(1,275 \mathrm{~km}^{2}\right)$ it is $1,429 \mathrm{~mm}$. It appears that 60 per cent of the total amount of annual rainfall occurs between June and September, 30 per cent from February to May, and only 10 per cent between October to January.

\subsection{Land Use/ Land Cover}

The main land use of the Woreda (Sekoru and Yem Special Woreda) is cultivation, livestock grazing and forest/bush land. The cultivated area comprises about $42 \%$ and $41.3 \%$ of the total area of Sekoru and Yem Woreda respectively. The present land utilization of Yem Special Woreda is estimated to be $45 \%$ cultivated, 
$20 \%$ grazing and shrub land, $9 \%$ woodland and forest, $15 \%$ potentially cultivable and $11 \%$ wasteland. In Yem Woreda the landholding area per rural household ranges from 0.5 to 2 hectares.

\subsection{Soils}

The Gilgel-Gibe river area (from the outlet of Gilgel Gibe I Hydroelectric project to the weir location). Due to the steepness of river banks, almost no vegetation and no soil are present in this area. From the inlet to km 15.3 of the tunnel stretch: this part is characterized by a relatively mature landscape, with blanket cover of residual soils and thick mantle of weathered rock. In this area the soils vary from Orthic Argisols in mountainous areas with steep slopes, to Orthic Luvisols in undulating hills between the slope that leads to Gilgel Gibe River and the highest and steepest part of the track. From $15.3 \mathrm{~km}$ to the outlet: the landscape has very young geomorphological features. In this area the topography is extremely steep and soil cover is sparse and most of the area is covered by weathered rhyolite talus and sporadic weathered outcrops. Locally there are some relict alluvial deposits.

\subsection{Hydrology}

The presence of Deneba reservoir has regulated the water flood in Gilgel Gibe River, and flood events have become insignificant for the population living between the dam and the confluence of Gilgel Gibe River in Gibe River.Building a weir about 33 meters height, with a minimum guaranteed runoff of $2.0 \mathrm{~m} 3 / \mathrm{s}$, the potential for downstream flooding still exists although reduced in extension and frequency of occurrence, because all water turbined by the Gilgel Gibe I Power Plant (about $100 \mathrm{~m} 3 / \mathrm{s}$ ) will be accumulated in the basin and diverted to the tunnel. The predicted daily drawdown is 3.3 hours; the reservoir will reach its full area of $0.15 \mathrm{~km} 2$ which will occur when the spillway would be close into the tunnel.

\subsection{Sediment storage}

During the construction phase, substantial effects on the characteristics of the sedimentation regime in the river section below the weir are not expected as the environmental management plan envisages erosion control caused by the construction through a constant on-site surveillance. In terms of operation, granulometric analysis indicates that most of the suspended sediment is represented by very fine particles of silt and clay. From the data obtained for the Gilgel Gibe I Project, the trap efficiency was expected to be in the range of 80 to $90 \%$; this means that the remaining $10-20 \%$ part would be the solid part of the water turbined by the Gilgel Gibe I Power plant. With a sediment content of the water outflowing from the power plant of $0.0255 \mathrm{mg} / 1$, the minimum volume of sediment content is 0.28 million $\mathrm{m} 3$ /year, and the maximum is 0.34 million $\mathrm{m} 3$ /year. Given the very small size of the particles and the limited head, no special abrasion problems are expected. The drawdown time (3.3 hours) is very fast to avoid sedimentation of these particles, so that it's expected that landfill phenomena will be negligible, and the dead storage of 1 million $\mathrm{m} 3$ is considered sufficient to ensure the proper operation for an economic life period of 25 years.

\subsection{Water quality}

Contamination of the future reservoir water from faecal matter and domestic wastes will not be a serious problem since all villages and individual house are far away from the reservoir location. Moreover due to the daily regulation, the retention time within the reservoir will be very short. The quality of water into the reservoir will maintain the main characteristics of the water upstream. There might be some pollution risks during the construction works: proper storage, handling and disposal of construction materials, particularly chemicals, fuels and lubricants must be strictly followed in order to prevent this kind of risks.

\section{Results and Discussion}

The Gilgel gibe II dam/reservoir and hydropower projects may have positive and negative impacts on the environment. The greatest impacts of the dam /reservoir are the result of impounding of water, inundation of land to create the reservoir and alteration of water flow regime on downstream areas These effects may have impacts on biophysical and human environment in the area. Possible impacts of the dam / water reservoir may include the following:

- $\quad$ soil erosion

- alteration of downstream flow regime

- land loss due to reservoir

- sedimentation

- health risks

- $\quad$ historical background

- cultural aspect 
- traditional way of life

- accommodation

- climate change

- loss of existing flora and fauna

Apart from its negative impact it has a positive impact through providing electric power for the whole nation and specifically for the people who are living around the proposed project, it provides the following benefits:

- job opportunity during construction

- construction of access road

- improved communication network

- solve sever water supply problems of the town

- Development of private business as a result of project construction

Table 1. Synthesis of environmental impact matrix

\begin{tabular}{|c|c|c|c|c|c|c|c|c|c|c|}
\hline \multirow{2}{*}{$\begin{array}{c}\text { Environmental } \\
\text { component }\end{array}$} & \multicolumn{5}{|c|}{ Construction stage activity component } & \multicolumn{5}{|c|}{ Operation stage activity component } \\
\hline & weir & tunnel & roads & $\begin{array}{l}\text { Power } \\
\text { house }\end{array}$ & substation & weir & tunnel & roads & $\begin{array}{l}\text { Power } \\
\text { house }\end{array}$ & substation \\
\hline \multicolumn{11}{|l|}{ Physical: } \\
\hline -seismology & 0 & 0 & 0 & 0 & 0 & 5 & 5 & 0 & 0 & 0 \\
\hline -hydrology & 3 & 0 & 0 & 0 & 0 & 2 & 5 & 0 & 3 & 0 \\
\hline -hydrogeology & 0 & 2 & 0 & 4 & 0 & 0 & 4 & 0 & 4 & 0 \\
\hline $\begin{array}{l}\text {-storage } \\
\text { sedimentation }\end{array}$ & 3 & 0 & 0 & 0 & 0 & 5 & 0 & 0 & 0 & 0 \\
\hline -water quality & 0 & 0 & 0 & 0 & 0 & 0 & 0 & 5 & 4 & 3 \\
\hline -climate & 0 & 0 & 0 & 0 & 0 & 0 & 0 & 0 & $\mathrm{~B}$ & 0 \\
\hline -downstream effect & 3 & 0 & 0 & 0 & 0 & 2 & 0 & 0 & 3 & 0 \\
\hline -landscape & 5 & 0 & 3 & 1 & 3 & 0 & 0 & 3 & 1 & 3 \\
\hline -slope stability & 4 & 0 & 3 & 3 & 5 & 2 & 0 & 3 & $\mathrm{C}$ & $\mathrm{D}$ \\
\hline -Disposal materials & 0 & 2 & 3 & 5 & 0 & 0 & 0 & 0 & 0 & 0 \\
\hline \multicolumn{11}{|l|}{ Natural: } \\
\hline -natural vegetation & 3 & 3 & 2 & 4 & 3 & 2 & 0 & 4 & 0 & 0 \\
\hline -fauna & 3 & 4 & 2 & 2 & 3 & 5 & 0 & 5 & 0 & 0 \\
\hline \multicolumn{11}{|l|}{ Socio-economical: } \\
\hline $\begin{array}{l}\text {-dislocation } \\
\text { people }\end{array}$ & 0 & 0 & 4 & 4 & 0 & 0 & 0 & 0 & 0 & 0 \\
\hline $\begin{array}{l}\text {-agricultural } \\
\text { resources }\end{array}$ & 0 & 4 & 3 & 5 & 5 & 0 & 0 & 0 & 0 & 0 \\
\hline -infrastructures & 0 & 0 & 0 & 0 & 0 & 0 & 0 & $\mathrm{~A}$ & $\mathrm{~A}$ & $\mathrm{C}$ \\
\hline -people's health & 3 & 3 & 3 & 3 & 3 & 0 & 0 & A & $\mathrm{D}$ & $\mathrm{D}$ \\
\hline -worker's health & 3 & 2 & 3 & 2 & 3 & 0 & 0 & 0 & 5 & 5 \\
\hline $\begin{array}{l}\text {-employment } \\
\text { opportunities }\end{array}$ & $\mathrm{A}$ & $\mathrm{A}$ & $\mathrm{A}$ & $\mathrm{A}$ & $\mathrm{A}$ & $\bar{E}$ & $\bar{E}$ & $\mathrm{~B}$ & $\mathrm{C}$ & $\mathrm{C}$ \\
\hline $\begin{array}{l}\text {-economic } \\
\text { development }\end{array}$ & $\mathrm{C}$ & $\mathrm{C}$ & $\mathrm{B}$ & $\mathrm{C}$ & $\mathrm{C}$ & 0 & 0 & $\mathrm{~B}$ & $\mathrm{~A}$ & $\mathrm{~A}$ \\
\hline -gender issues & 0 & 0 & $\mathrm{D}$ & $\mathrm{D}$ & $\mathrm{D}$ & 0 & 0 & $\mathrm{C}$ & $\mathrm{C}$ & $\mathrm{C}$ \\
\hline
\end{tabular}

\section{Positive impact}

A-very important

B-more important

C-important

D-fair important

E-less important
Negative impact

1 -very important

2-more important

3-important

4-fair important

5-less important 0-no important 
Table 2. Environmental receptors of impacts

\begin{tabular}{|c|c|c|}
\hline \multirow{2}{*}{ receptors } & \multicolumn{2}{|c|}{ Description of potential impacts (positive/negative) } \\
\hline & Pre-during construction & During normal working operation \\
\hline Air quality & $\begin{array}{l}\text { Dust production; } \\
\text { Transport pollution }\end{array}$ & $\mathrm{CO}_{2}$ emission reduction \\
\hline Surface water & $\begin{array}{l}\text { River flow alteration; } \\
\text { Pollution hazards; } \\
\text { Water resource availability }\end{array}$ & $\begin{array}{l}\text { River flow alteration in the Gilgel gibe; } \\
\text { Flood control; } \\
\text { Better use of water resources }\end{array}$ \\
\hline $\begin{array}{l}\text { Underground } \\
\text { water }\end{array}$ & Water disturbances & Water disturbances \\
\hline Soil & $\begin{array}{l}\text { Land occupation for allocating } \\
\text { excavated materials }\end{array}$ & $\begin{array}{l}\text { Reduction of soil erosion due to the reduction of wood } \\
\text { cutting for local energy production }\end{array}$ \\
\hline Geomorphology & Construction spoils & Stability of the disposal area \\
\hline Flora & Destruction of natural forest & Destruction of natural forest in the disposal areas \\
\hline Ecosystems & Local ecosystem disturbance & Alteration of the local ecosystem \\
\hline \multirow[t]{3}{*}{ Socio-economy } & Employment opportunity & Employment opportunity \\
\hline & Health risk & Family income and structure \\
\hline & Customs of imported workers & $\begin{array}{l}\text { Opportunities due to the availability of power; } \\
\text { Infrastructure development }\end{array}$ \\
\hline health & $\begin{array}{l}\text { Sanitary condition at camps; } \\
\text { Car accidents; } \\
\text { Diffusion of sexually transmitted } \\
\text { diseases }\end{array}$ & $\begin{array}{l}\text { Sanitary conditions inside the power house and in the } \\
\text { substation area; } \\
\text { Water quality due to waste water production in the } \\
\text { power house }\end{array}$ \\
\hline
\end{tabular}

\section{MITIGATION MEASURES}

Mitigation measures are required based on priorities to avoid or minimized the adverse impacts that will be resulted due to the project implementation. To this end, possible management or mitigation measures have proposed against identified negative impacts of the project. The following table describes mitigation measures that should be taken in to account:

Table 3. Mitigation measures for adverse Environmental Impacts

\begin{tabular}{|c|c|c|c|}
\hline \multicolumn{2}{|c|}{$\begin{array}{l}\text { Environmental component and } \\
\text { Impact }\end{array}$} & \multirow{3}{*}{$\begin{array}{l}\text { Causes } \\
\text { impounding of water in } \\
\text { the reservoir }\end{array}$} & \multirow{2}{*}{$\begin{array}{l}\text { Mitigation measures } \\
\text { - } \quad \text { proper release of water for the downstream } \\
\text { - } \quad \text { proper reservoir operation }\end{array}$} \\
\hline \multirow[b]{2}{*}{ 1. Hydrology } & \multirow{2}{*}{$\begin{array}{l}\text { Flow regime } \\
\text { alteration }\end{array}$} & & \\
\hline & & & $\begin{array}{l}\text { - } \begin{array}{l}\text { Controlled release of water to the } \\
\text { downstream }\end{array} \\
\end{array}$ \\
\hline 2. Pollution & $\begin{array}{l}\text { Toxic } \\
\text { substances }\end{array}$ & $\begin{array}{l}\text { Excavation of the } \\
\text { ground in deep; } \\
\text { During construction } \\
\text { from vehicles(emission } \\
\text { of toxic gas) }\end{array}$ & $\begin{array}{l}\text { - Detail study of underground materials as } \\
\text { per their chemical nature } \\
\text { - Use small number of vehicles }\end{array}$ \\
\hline Sediment & Erosion & $\begin{array}{l}\text { land clearing and } \\
\text { earth excavation } \\
\text { works } \\
\text { deforestation and } \\
\text { clearing of trees }\end{array}$ & $\begin{array}{l}\text { - } \quad \text { implementation of watershed management } \\
\text { - area closure of exposed and degraded } \\
\text { areas }\end{array}$ \\
\hline & Sedimentation & $\begin{array}{l}\text { Improper disposal of } \\
\text { waste excavated earth } \\
\text { materials }\end{array}$ & $\begin{array}{l}\text { - Construction of sediment traps and check } \\
\text { dams } \\
\text { avoid damping of waste earth materials on } \\
\text { water courses }\end{array}$ \\
\hline 4. Ecology & $\begin{array}{l}\text { Project lands } \\
\text { Water bodies } \\
\text { Wetland and } \\
\text { plains }\end{array}$ & $\begin{array}{l}\text { land clearing and } \\
\text { cutting of natural } \\
\text { vegetation in the } \\
\text { project area and the } \\
\text { surroundings }\end{array}$ & $\begin{array}{l}\text { - Improve vegetation cover condition of the } \\
\text { project area with planting of } \\
\text { multipurpose trees }\end{array}$ \\
\hline
\end{tabular}




\begin{tabular}{|l|l|l|l|}
\hline \multicolumn{2}{|c|}{$\begin{array}{l}\text { Environmental } \\
\text { and Impact }\end{array}$} & \multicolumn{1}{|c|}{ component } & Mitigation measures \\
\hline $\begin{array}{l}\text { 5. Soico- } \\
\text { economic }\end{array}$ & Resettlement & $\begin{array}{l}\text { Loss of land and properties } \\
\text { due to dam and reservoir }\end{array}$ & $\begin{array}{l}\text { proper compensation } \\
\text { allocation of land for } \\
\text { affected people } \\
\text { settlement }\end{array}$ \\
\hline 6. health & $\begin{array}{l}\text { Outbreak of } \\
\text { diseases }\end{array}$ & $\begin{array}{l}\text { malaria due to spread of mosquito } \\
\text { in the stagnant water in the } \\
\text { reservoir } \\
\text { HIV/AIDs due to deployed of large } \\
\text { number of daily workers }\end{array}$ & $\begin{array}{l}\text { primary Health education } \\
\text { spray anti mosquito } \\
\text { chemicals } \\
\text { clearing of stagnant waters } \\
\text { in the clans and depressed } \\
\text { areas }\end{array}$ \\
\hline
\end{tabular}

\section{CONCLUSION}

The Gilgel gibe II hydropower development project will bring about many changes to the bio-physical and socio-economic environment in the project area as well as to the surroundings. The main objective of the project is to enhance and diversify power production and thereby to ensure the electric power requirement of the country.

Although they can be managed through proper mitigation measures, the project may also result some significant adverse impacts on the environment. Therefore, proper mitigation measures need to be considered at each stages of the project implementation including construction to operation, if not it will result distressing challenges both to the environment and sustainability of the project.

Finally, it is suggested that integrated watershed management program need to be considered in the whole gibe watershed as the integral part of the environmental planning to ensure healthy environment in the project area and conserve the environment and ensures the sustainability of the project.

\section{References}

[1] Adrien Lantieri, Zuzana Lukacova, Jennifer Mc Guinn, and Alicia McNeill, (2017). Environmental Impact Assessment of projects; guidance for the preparation of the environmental impact assessment reports, louxenberg.

[2] FAO, (2011).Environmental Impact Assessment guidelines for FAO field projects, Rome, Italy.

[3] JF Mock and P Bolton, (1993). The ICID checklist to identify the environmental effects of hydropower and flood control projects, HR Walling Ford.

[4] Kariuki Muigua, (2012).Environmental Impact Assessment (EIA) in Kenya, Nairobi, Kenya.

[5] Meskir, (2008). Environmental policy and Laws of Ethiopia and clean fuel, Addis Ababa, Ethiopia

[6] MoWR, (2000). Ethiopian Water Resources Management Policy. Addis Ababa.

[7] MoWR, (2002).water sector development program, main report, volume II.

[8] Richard Woodroofe \& Associates. (1996) Omo-Gibe River Basin Integrated Development Master Plan Study Final Report.

[9] Tenalem A., (2007). Some improper water utilization practices and environmental problems in Ethiopian rift valley. Africa water journal. Vol. 1, No. 1.

[10] Tord Céwe, John McEwen, Mikael Hildén,Eeva Furman,Seija Korhonen, Joe Nazareth, Marianna Novikova, Richard Wildermann, Kjell Moe, Gunnar Futsæter, Holmfridur Sigurdardottir and Violet Ford, (1997). Guideline for environmental impact assessment (EIA) in the arctic, arctic environmental protection strategy, finish ministry of environment, Helsinki. 